\title{
Policies and Practices of Nature Conservation in Africa: Ideological Challenges, Bottlenecks and Strategic Vision and Options for Protected Areas Sustainable Management
}

\author{
Ntiranyibagira Elysée ${ }^{1,2, ~ *}$, Umuziranenge Gloriose ${ }^{3}$ \\ ${ }^{1}$ Department of Environmental Sciences and Technologies, Faculty of Agriculture and Bio-Engineering, University of Burundi, Bujumbura, \\ Burundi \\ ${ }^{2}$ Center for Expertise, Research and Training in Environment and Sustainable Development, (CERTED), Bujumbura, Burundi \\ ${ }^{3}$ Department of Environment and Natural Resources Management, Faculty of Development Studies, Protestant Institute of Arts and Social \\ Sciences, Huye, Rwanda
}

Email address:

ebagira2010@yahoo.fr (N. Elysée)

${ }^{*}$ Corresponding author

\section{To cite this article:}

Ntiranyibagira Elysée, Umuziranenge Gloriose. Policies and Practices of Nature Conservation in Africa: Ideological Challenges, Bottlenecks and Strategic Vision and Options for Protected Areas Sustainable Management. International Journal of Sustainable Development Research. Vol. 6, No. 4, 2020, pp. 55-72. doi: 10.11648/j.ijsdr.20200604.12

Received: July 21, 2020; Accepted: August 3, 2020; Published: December 25, 2020

\begin{abstract}
Africa is the continent of nature conservation per excellence, the testing ground for conservation policies and the symbol of degradation of protected areas worldwide. Though the internalization of international conservation policies and standards has had positive impacts on the extension of protected areas networks, these ones are undergoing increased pressure that considerably threaten biodiversity. Such evolutions call for a revision of the management systems on the basis of preliminary indepth and rigorous analysis of conservation policies and practices. The study aimed to: (1) explore and synthesize the state of art on conservation policies and practices, (2) identify and analyze the gaps existing between management standards and field practices and (3) detect challenges and bottlenecks and define innovative strategic options for efficient and sustainable management. The research relies on the interpretative synthesis and analysis of the hudge literature available on the nature conservation. The results showed that the dominant model of inhabited protected areas and social exclusion broke the historical harmony between populations and natural resources, disrupted traditional ways of life and generated devastating and continuous social conflicts. They revealed that the lack of management tools, the limits of eco-tourism, the inefficiency of participatory programs and the financial gaps lead to increased anthropic pressures and degradation that have transformed most of protected areas into open agro-pastoral parks. More specifically, the lack of management goals, categories and plans for most of protected areas and the absence of appropriate and regular assessments generate visual navigations and improvisations in management systems that result into glaring discrepancies between theoretical management categories and field practices that have globally failed to maintain original situations or to induce progress. Finally, the poor performance of the management systems results from conflicts of ideologies, interests and agendas between actors having strongly imbalanced means, positions and powers. Such conflicts come from the primacy of powerful external actors, the central role of national governments and the democratic deficits in the management mechanisms, the preeminence of ecological interests over socio-economic benefits, the selective international funding, the emerging privatization of conservation and the marginalization of local communities. To address these ideological and practical challenges, prior and deep assessments of management systems are needed for strategic declassifications, reclassifications and classifications of protected areas before the promotion of rebalanced powers between actors in favor of local communities, administrative and financial autonomies, community based joint shareholdings, double universal mechanisms for compensatory financing and domestic patriotic tourisms.
\end{abstract}

Keywords: Conservation Policies, Conservation Practices, Ideological Challenges, Community Conservation, Sustainable Compensation, Management Autonomy, Africa 


\section{Introduction}

Today, protected areas and biodiversity represent multiple and important interests for different actors involved in the management of natural resources [1-4]. The diversity of interests, the complexity of actors and the variability of strategies lead to enormous exploitation pressures that threaten biodiversity at all scales. To give an example, biodiversity would have decreased by $30 \%$ globally and by $60 \%$ in the tropics between 1970 and 2008 [5]. The degradation of the biodiversity has been accompanied by a considerable loss of ecosystem products and services of which $60 \%$ would have deteriorated globally [6].

These trends would result from several factors, including the predominance of direct socio-economic benefits over the indirect benefits of conservation or ecological services and the impacts of climate change [6-8]. While the global system of protected areas is one of the most effective solutions for the adaptation to climate change and the mitigation of its effects [7], $89 \%$ of the world's natural systems already suffer from adverse effects of climate change [9]. In this context, projected climate changes call for the revision of current assumptions, plans and tools for protected area management [9-11].

This initiative should lead to fundamental innovations for continuous adaptation of the management goals and systems of degraded or threatened ecosystems. To be credible and effective, the adaptive and dynamic management model must emerge from a rigorous critical analysis of the conservation policies and practices, as they have evolved around the world and in Africa, considering the states of conservation. It should break conventional ideas, relativize internationally made standards and question the ideological recycling that rarely produces new field management practices. The indepth assessment of the appropriateness, relevance and effectiveness of the conservation policies and practices is of particular interest for Africa which represents the continent of conservation per excellence, the testing ground for international conservation policies and the symbol of degradations of protected areas in the world [12-14].

Since the colonial period, the creation of African protected areas has systematically been inspired by international conservation policies and standards under the influence of the International Union for the Conservation of Nature (IUCN) and the Trinity of the conservation composed of World Wildlife Fund for Nature (WWF), The Nature Conservancy (TNC) and Conservation International (CI) [15-16]. The internalization and national ownership of these policies and standards have had largely positive impacts on the extension of national networks of protected areas on the continent. With 2.4 million $\mathrm{km}^{2}$ of protected areas covering $14.7 \%$ of its global area, Africa now has one of the largest networks of protected areas in the world [16].

At regional levels, protected areas cover $10.5 \%$ of West and Central Africa and $14.5 \%$ of Southern and Eastern Africa [14]. At national levels, the coverage of protected areas of African conservation champions such as the Central African Republic, Cameroon and Equatorial Guinea exceeds $20 \%$ of the territory $[14,17]$. In addition, while the continent has only $3.3 \%$ of the protected sites in the world, of which $65.6 \%$ are located in Europe, it has the highest proportion of large protected areas which are generally national parks because $52 \%$ of them cover more than 100 $\mathrm{km}^{2}$ each [16]. With very few exceptions, such as Rwanda which lost more than $50 \%$ of the original extent of protected areas following decommissioning for the settlement of landless returnees [18], African countries have continued to expand their protected areas networks since the 1960s, despite increased demands for agricultural and livestock land, deep land-related tensions and a world trend towards subsidence [19-20]. The Aichi Targets and their Strategic Action Plan for the Expansion of the Global Network of Protected Areas by 2020 [21-22] have further boosted the dense African network of protected areas.

These dynamics widely praised by the international conservation community, were however been based on the break of the historical human-nature relationships that have long ensured the sustainable management of natural resources through community regulations. Across Africa, the creation, extension and status changes of protected areas have generally been accompanied by forced evictions of local populations $[23,1,24]$ and the setting up of military or paramilitary administrations to avoid or limit inevitable pressures coming from the populations driven out from the places. However, protected areas are continually experiencing increased exploitation pressures and severe degradation in a way that the majority of them would be dangerously endangered or would only exist on paper [25].

Actual, the population growth, the rising of energy demand and the increasing urbanization that are usually blamed for the continued and significant degradation of protected areas [26-30, 5] do not justify enough observed declines in conservation. Conservation policies and practices that are largely inspired by the North American ideology of "protected areas empty or emptied of men" [31] which dedicates the total absence or inequalities of access to natural resources for rural populations depending exclusively on the primary sector and natural areas that were historically inhabited and anthropized $[32,1]$ should contribute to these negative trends. Indeed, they are the ones that determine or direct spatialized peripheral socio-economic interactions and therefore, the evolution of protected areas themselves [33-35]. On one hand, the present study aims to explore the conservation policies and practices from the beginning of normative classifications in the $19^{\text {th }}$ century up to now for critical analysis and to identify the incoherence, contradictions and bottlenecks strangulation that jeopardize the effectiveness of the nature conservation. On the other hand, it is intended to define an ideological re-foundation of conservation strategies that will ensure effective conservation, sustainable use of natural resources and equitable sharing of the benefits of the biodiversity management. 


\section{Method and Materials}

The method adopted by the study relies on three stages, namely: (1) a broad exploration and an interpretative synthesis of normative ideological currents, policies and practices of conservation in the world and in Africa, (2) a rigorous and critical analysis of conservation policies and practices in Africa and an identification of inconsistencies, contradictions, bottlenecks and uncertainties that undermine the effectiveness of conservation in Africa; and (3) the definition of alternative ideological options and strategies to ensure the effectiveness and sustainability of conservation on the continent. The study used the following documents and sources of data: (i) international conventions and policy documents on nature conservation, (ii) theoretical bibliographic data and scientific publications on nature conservation, and (iii) quantitative and qualitative empirical data from periodic reports of international and national institutions and services specialized in nature conservation.

\section{Synthesis of Knowledge and the State of Art in the Field of Conservation}

\subsection{Evolution of Conservation Policies}

Historically, it is the mystic and religious considerations that motivated the creation of former protected areas often called "sacred forests" in indigenous societies of the tropical world and considered as the first protected areas in the world [36]. Actually, these are integrated spaces of life, production and cultural expression that are subject to regulated and sustainable community management by means of ancestral customs and specific ritual practices. This is what we name the first time of conservation or the time of man-nature harmony characterized by essential extractions and nonmarket uses of vital resources.

Protected areas of the modern era appeared in the second half of the $19^{\text {th }}$ century with the creation of the emblematic Yosemite Regional Park and the Yellowstone National Park in the United States of America, respectively in 1864 and in $1872[31,1,24]$. Since that period, the dynamics of creation of protected areas will spread in Europe and irradiate in Africa through European colonization. On the African continent, it is the Kruger National Park created in South Africa in 1898, the Albert Park known today as the Volcano National Park established between the Democratic Republic of Congo, Rwanda and Uganda in 1925 [37, 38], the Akagera and Nyungwe National Parks established in Rwanda in 1933 [39] and the Waza National Park established in Cameroon in 1934 which are the first modern protected areas.

Here, things take a new direction in the design and purpose of protected areas that are based on the principles of social exclusion and openness to external tourism. Protected areas now respond to the growing need of civilized and urban populations to relax through walks in parks and reserves known for their aesthetic, landscape and tourist qualities [31, 1 , 24]. The founding idea of vision tourism will become the universal driver of conservation policies around the world. In Africa, specifically, the creation of protected areas focused on natural areas of high tourist interest by targeting strategic hunting areas and endemic species that can feed Western world mass tourism [40, 41, 14]. As wild animals have become "things to think about" for rich urban populations rather than "things to eat" for poor local people [1], it is the savannahs full of wild animals of which the "charismatic mega fauna" or the "big five" (Elephants, Rhinoceros, Hippopotamus, Buffalo, Lions) that fit exactly the Western world idea of wilderness, game reserves and national parks [14].

In very rare situations, however, especially in the mountainous areas of Central Africa, the creation of protected areas was primarily a matter of water and soil conservation to fight erosion and water imbalances $[42,18]$. As a general rule, the creation of African protected areas has been carried out in violation of the interests and dignity of indigenous peoples and has deeply altered traditional ways of life $[31,1,24]$. Almost everywhere, the process was conducted in pain and desolation because it involved massive and militarized expulsions of local populations [43-44, 39, 1, 14]. Like the sad experience of some native tribes in the creation of American national parks, several peoples lived very bad moments in different parts of the continent [45-47, $32,48,1,19,24]$. They were suddenly and violently deprived of free access to key natural resources like crop lands, pastures and water resources, without other alternatives for survival $[48,38]$.

In facts, protected areas have become "food pantries surrounded by hunger" [49] that are permanently exposed to desires of marginalized peripheral populations, ruling elites, private economic operators and even rebel movements [43, 25, 20]. This kind of conservation policy based on the American vision of "uninhabited and uninhabitable protected areas" [31] will ideologically mark the establishment and the considerable extension of African national networks of protected areas until the 1980s [41, 1, 50,14, 19]. This is the second time of conservation or the time of the fortress conservation characterized by the prohibition of access and use of protected resources.

In the aftermath of African independence, growing challenges to the continuation and the strengthening of colonial conservation policies will force Western conservationists to open up an era of international negotiations and develop new arguments to convince skeptical leaders of the interest of the conservation [49, 32, $12,13]$. To this end, the African conferences of Arusha (Tanzania) and Algiers (Algeria) held respectively in 1961 and 1968 will have a great impact on the maintenance, the extension and the creation of protected areas in Africa [51, 18]. They promoted tourism as a major opportunity for independent governments to increase financial revenues and launch their young economies [13]. This strategy of legitimizing conservation through socio-economic arguments was pursued through the concepts of "sustainable development" and of "integration of populations" that appeared with the World Conservation Strategy in the 1980s 
$[52,32,34]$. It was reinforced by the concepts of "Ecosystem Products and Services" and of "Economy of Ecosystems and Biodiversity" that have been developed in the 2000s [6, 53].

The integration between conservation and development is an indirect conservation strategy based on integrated conservation and development projects (ICDPs) that relies mainly on ecotourism development projects in forest areas $[12,54,25]$. It opens the third time of conservation or the time of the participatory approach based on the involvement of local populations in the economic valorization of biodiversity and the redistribution of its benefits. This new conservation approach has gradually emerged as a universal model for the management of protected areas, particularly with the emergence of decentralization policies in Africa during the decade $1980[12,55,2]$. In principle, it came to break the North American model of "uninhabited and uninhabitable parks" which deeply upset the socio-economic and cultural order of the native populations, by considering the objectives of sustainable development and the interests of the local populations [56].

The major arguments that supported the participatory approach are the following: (1) most of natural ecosystems that were under protection in the colonial period were largely anthropized [23, 32]; (2) protected areas particularly conserved by native peoples loose less forest than areas under other management systems [32, 56-58], (3) national governments having not enough resources for interventions, local populations with a strong knowledge of biodiversity should be key and alternative actors for better control of the use of natural resources, once motivated and appropriately incentivized [59, 7] and (4) the transfer of protected areas and natural resources management to local communities was consistent with the decentralization policies of the 1980s [7, 34]. In thinking and practice, three major inflections have marked the participatory approach, namely: (1) the shift from centralized and state governance to local participatory governance, (2) the re-conceptualization and refocusing of conservation on the notion of sustainable development and (3) the incorporation of liberal ideas and the use of market forces to finance conservation $[60,12]$.

Because of the recurrent financing difficulties, the weak performances or even the failures of participatory management and the continued degradation of protected areas, deep ideological antagonisms still oppose defenders of fortress conservation or complete protection of richest natural areas in biodiversity and advocates of a participatory management approach that reconciles forest conservation and local development [61]. The conservationist communities with high financial capacities are openly showing renewed interest for the fortress conservation approach that appears through the definition of priority conservation and funding areas such as WWF Ecoregions, CI Biodiversity Hotspots and TNC portfolios [41, 62-64, 19] and the abandonment of participatory management approaches by international financing mechanisms. This is the fourth time of conservation or the time of selective and large-scale fortress conservation.
It is within the framework of the implementation of these global conservation policies that we see emerging regional governance initiatives in the form of politico-technical structures and bodies for the harmonization and the coordination of actions. This is particularly true for transboundary protected areas that are facing national legislative discrepancies and need concerted action frameworks, as single geographic entities. This is the case of the Conference of Ministers of Central African Forests (COMIFAC), the Central African Forest Ecosystems (ECOFAC) and the Protected Areas Network of Central Africa (RAPAC) which were set up with the support of international donors and conservation NGOs $[65,66]$.

In order to overcome the persistent ideological opposition and the heated and unsuccessful debates that it is feeding, a new conservation approach based on the paradigm of "You should pay for what you want to get" or "You should pay for conservation and not for conservation related activities " was recently proposed [67, 68]. According to the authors, biodiversity is in danger in developing countries because the material benefits that local populations derive from its destruction far exceed what they expect to gain from its preservation [69]. This still theoretical conception of conservation opens or prefigures what should be the fifth time of conservation or the time of real compensatory merchant conservation.

In fact, the basic question is the direct and indirect financing of conservation. In terms of funding, conservation policies provide two major mechanisms, namely: (1) external subsidies that are defined according to the specific ecological importance of protected areas and (2) fees and duties generated by products and services provided by protected areas [70]. This clearly means that income from resource exploitation and ecotourism must be reinvested in the management of protected areas. Between the two funding sources and in the context of responses to climate change adaptation, [71] identifies three sources of funding that are: (i) private and public financing, (ii) commercial financing, and (iii) financing under the form of subsidies.

According to other authors, the national benefits of conserving biodiversity such as the willingness to pay resource users downstream of protected areas and ecotourism are two potential sources of sustainable funding for the cost of the management of protected area networks [72]. To achieve efficient and sustainable protected areas management, financial planning and self-financing mechanisms based on rational exploitation of resources are needed for sound and credible business plans that should attract the private sector and additional resources in the framework of public-private partnerships [73].

In summary, nature conservation policies in Africa can be divided into five crossed times or periods: (1) from the precolonial period to the start of the colonial period in the $19^{\text {th }}$ century, when customary law and community regulations were guiding resources management, (2) from the colonial period to the independence of nations and years 1970-1980 when the fortress conservation was the key word, (3) from 
the decade 1980 up today when the participative approach is the leading conservation method supported by various tools and instruments, (4) from the 2000 s to present time when policies of sanctuary management of priority and selective regional areas re-emerge from big conservation international NGOs and (5) from years 2002-2003 up today when theoretically emerges a truly merchant and equitable conservation approach that has not yet shaped up. These conservation policies are inspired by four paradigmatic currents that govern human-nature relationships, namely: (i) the utilitarian or unregulated approach and (ii) the resourcebased or regulated approach with management plans and anticipative restrictions that are anthropocentric, (iii) the preservationist or non-use approach that is bio-centric, and (iv) the conservative or limited-use approach that is ecocentric $[13,74]$.

\subsection{Evolution of Conservation Practices, Models and Tools}

The section shows how the conservation policies have been materialized and reflected into conservation practices and actions. In theory, conservation practices are based on the main characteristics of a protected area that emerge from internationally-agreed normative definitions $[75,76]$. As the definition of the CBD is a minimal statement that results from difficult negotiations and political compromises and is unclear on conservation goals, the characteristics drawn by the UICN definition were considered in the study, namely: (1) the existence of precise geographical boundaries, (2) the existence of a mechanism of recognition and management, and (3) the focus of conservation goals on ecosystem services and cultural values.

In Africa, where national parks are by far the most common type of protected areas, management practices are also based on the attributes of the standardized definition of a national park, namely: (i) a large territory containing one or more ecosystems, (ii) the absence or low level of human occupation and exploitation, (iii) the highly aesthetic and touristic character of sites, habitats and species, and (iv) the restriction of human uses to research, education and recreation [34]. In the framework of fortress conservation, the first two criteria imply large population displacements and serious limitations, and even deprivations of access to protected resources, which are also applicable to the many natural forest reserves in Africa.

In order to avoid exploitation pressures resulting from peripheral populations driven out of protected areas, these ones are most of the time endowed with militarized or paramilitary administrations, as in the United States of America, where, however, they have only survived until 1916 $[1,18]$. Later, the legislations evolved towards the creation of buffer zones of 500 to $1000 \mathrm{~m}$ large from the limits to compensate socio-economic losses and reduce the anthropogenic pressures of peripheral origin [43, 18, 20]. For that purpose, pilot participatory projects focused on green jobs of the types "Work for Water", "Work for Wetlands", "Food for Work" and "Wood for Work" were launched and promoted around protected areas on the continent $[2,77,20]$.
In the framework of participatory approaches that have been codified and standardized internationally since 2004, through the Working Program on Protected Areas [78, 14, 22], high levels of protection must be embedded in socially and culturally acceptable processes for fair compensation and fair allocation of costs and benefits [7]. To allow minimal access to vital resources and to compensate the limits of ecotourism [79-81], national parks could be dismembered into several protected areas managed under various statutes with adequate zonings combining a wide range of management approaches and categories [80].

The aim of such strategy is to build a multi-category network of sanctuary protected areas in the center (categories I, II, III) and buffers with less strict protection around (Categories IV, V, VI), while excluding degrading activities such as clear cuts, industrial plantations and unsustainable extractions of resources [82]. These areas or zonings with multiple regimes of protection often consist of: (i) zones under integral protection, (ii) reserves for the management of species and habitat, (iii) ecological corridors or bio corridors for the migration of wildlife, and (iv) buffers for the compensation of imposed deprivations [80].

In terms of management practices, protected areas refer to a wide variety of goals, management models and legal statutes [19]. Since the $4^{\text {th }}$ World Congress on Protected Areas held in Caracas (Venezuela) in 1992, the international typology recognizes 7 categories of management goals numbered from I to VI, that are defined according to the types of use and interventions authorized within protected areas $[76,83,79,14,84]$. It also recognizes two special categories of UNESCO that are "Biosphere Reserves" that can be modeled on each category of management and "World Heritage Sites" [79]. In principle, periodical assessments and the analysis of consistency between the management categories and the management practices allow to modify or to adapt the management categories if the actual management methods do not fit to them [80]).

Similarly, the transformation of existing protected areas into parks and nature reserves should not be used as a pretext for dispossessing the inland or peripheral populations of their lands [80]. In terms of governance or of the structure and the management of the decision-making power [85], the typology decided by the $5^{\text {th }}$ World Congress on Protected Areas held in Durban (South Africa) in 2003 recognizes 4 types of governance that are applicable to each of the 7 management categories [80, 7]. In Africa, protected areas are gradually moving from state governance (Type A) towards co-managed governances (Type B), except in few countries like Rwanda where all the protected areas remain totally under the state governance [20].

At the same time, we see progressively emerging new protected areas under community governance (Type C) and private governance (Type D). In terms of participatory management, the legal solutions proposed are of three types, namely: (1) the creation of community protected areas on the initiative and under the direct management of local populations, (2) the financing of income-generating activities 
with the revenues from protected areas exploitation; and (3) the direct employment of local people in protected areas management [77].

The sources of financing of income-generating activities include taxes, miscellaneous fees and conservation budgets, in this case royalties on sport hunting concessions in village hunting areas [77]. Usually, collaboration agreements are in the form of contracts between the public or private manager and the neighboring or peripheral villages [86, 77]. The technical and financial management tools are the management plans [88-90], the business plans [73] and the assessment models of management effectiveness [91-93].

The current models of assessment used for the adaptation of the management modes and judicious allocation of financial resources are the following: (i) "Pressure, State, Responses" (PSR) [94]; (ii) "Driving forces, Pressure, State, Impact, Responses" (DPSIR) [95], (iii) the "Management Effectiveness Tracking Tool for Rapid Assessment and Prioritization of Protected Areas Management" (METTRAPPAM) (IUCN), (iv) the "World Commission on Protected Areas Assessment Framework" (IUCN), (v) the "Protected Areas Benefit Assessment Tool" (PA-BAT) [7], (vi) the African Protected Areas Assessment Tool (APAAT) [96] and (vii) the Protected Areas Trends Assessment and Adaptive Management on the basis of long terme Conservation Objectives (PA-TAMCO Analytic Model) [97].

After the developments about the conservation policies and practices, we analyze and present hereafter the differences between international standards and actual management practices in order to identify inconsistencies, contradictions and bottlenecks that characterize the conservation sector before proposing our vision for effective conservation and sustainable use of natural resources in Africa.

\section{Critical Analysis of Conservation Policies and Practices}

\subsection{Travers, Implications and Setbacks of Conservation Policies}

In the pre-colonial period, the effective and sustainable management of African natural ecosystems relied on traditional beliefs, ancestral customs, and community-based management mechanisms [57, 43]. Through exclusionary policies in conservation and religious missions, European colonization and its Western lobbies have fundamentally disrupted traditional ways of life of the people by breaking the historical relationship to nature and the management rules of territories and natural resources [98, 57, 32, 43]. By forcing the almost systematic eviction of indigenous peoples from protected areas and the brutal abandonment of ritual practices in many sacred forests [23, 1, 99], the founding myth of conservation policies based on "a primitive, wild, uninhabited, and uninhabitable nature" where man is a visitor who does not stay long [1] and "protected areas empty or emptied of men" [31] engendered permanent hostility from local populations that lead to increasing illegal exploitations and continued degradation of natural ecosystems that have traditionally been well managed and safeguarded [32, 43, 7, 20].

Indeed, the incompatibility between man and nature set by the two pillars of the global conservation policy embodied by the Yellowstone national Park [1, 24] and the sanctuary management model did not at all fit to historical, socioeconomic and cultural realities [32]. Firstly, the myth of "wilderness" that makes one believe in the virginity of natural ecosystems that man has never changed and the incompatibility of national parks with the permanent human presence is an illusion, if not a nonsense [32, 44]. Secondly, the establishment of protected areas for the exclusive enjoyment of wealthy visitors from cities and elsewhere, given the touristic qualities of sites and species, did not meet any discernible and relevant demand in African socio-cultural contexts [20].

Despite progress in international conservation policies on social openness and participatory management since the 1980s, African protected areas remain large and largely uninhabited at a time when $70 \%$ to $85 \%$ of the world's protected areas are partly or fully occupied [56] and when the world global trend is dominated by small soft-protected areas $[100,101]$. The recognition and reality of human interventions in the majority of protected areas in the world allow to reject the idea of protection "against humans" in the absolute as indicated by some critical authors [102]. They confirm that the fortress conservation of tropical natural areas is a kind of ecological extremism and interference as already stated by other researchers [32].

In reality, the dichotomy between "natural areas" and "man-made areas" is illusory because all regions of the world have experienced or are experiencing a variable degree of artificialisation [32, 56]. Thus, the abusive pursuit of forced displacements of populations in the creation, extension and changes of status of protected areas and the maintenance of these outside the sphere of socio-economic action are always felt as serious attacks to the rights of local communities over confiscated lands that lead to chronic food crises and hunger $[23,32,48,12,18]$. The socio-economic losses suffered by local populations are the more important and damaging than the majority of African protected areas are centered on wetlands, large rivers and good agro-pastoral lands [103, 20]. The recurrent situations of ecological and touristic priority over socio-economic benefits make African protected areas "foreign territories" to local communities [20] and "pantries surrounded by hunger" [49] which are only useful for "foreigners and national elites", especially through tourism activities and revenues [43, 1, 14].

Actually, African protected areas have become geopolitical instruments for independent states where land dispossession, social exclusion and external appropriation of natural areas and resources replaced in the state domain reinforce poverty and generate significant social conflicts $[23,250,74,7,20]$. The exception or better, the African rule of "uninhabited parks and protected areas" proceeds in principle from an 
imported and imposed governance that perpetuates the colonial conservation policies in opposition to vital interests of local communities [104]. In Africa, the reference of protected areas to wildlife, hunting activities and tourism, which is permanent in conservation philosophy, rhetoric and practices $[43,1,25]$ generates and maintains multi-faceted stresses among local populations who are constantly confronted to the destruction of crops, properties and human lives by wild animals that feed the Western vision tourism $[32,43]$.

In the absence of relocation and fair and equitable compensation for physical evictions and material destructions, indigenous peoples remain confined to the peripheries of protected areas from where they develop rejection feelings, open hostility and rebellious behaviors [43, 1, 14, 35]. Protected areas in general and national parks in particular are subject to intense anthropogenic pressure and degradation, more because of social exclusion and inequalities in access to resources than because of rapid population growth and increasing urbanization, contrary to official speeches [105, 20].

Consequently, we realize and note that the substitution of the "state constraint" to the "community civic awareness" and of the "international arbitrariness" to the "local rationality" creates a permanent struggle of interests between the conservation authorities and local communities who finally and openly fight against the spoliation of their land [48]. In this context too, the international framework of participatory management approaches constitutes a paradoxical negation of the traditional knowledge and knowhow in the effective management of biodiversity and a major obstacle to the free choice of types and forms of sustainable exploitation of resources. The incrimination of local communities in the degradation of protected areas by conservationists is also expressed by their strong opposition to the new participatory management categories $\mathrm{V}$ and VI from Durban Congress on protected areas that are struggling hard to take place in Africa [106].

Contrary to the fortress conservation management categories I to III favored by conservationists, donors and national governments themselves, management categories IV to VI where human interventions are authorized are rare in Africa where states still play a central role in the regulation and legislation of participatory management $[25,93,20]$. At the same time, state mistrust of groups of citizens escaping or being beyond its control severely limits achievements in community and private managed protected areas [77]. Through the relegation of social concerns in decision-making [107], regional and selective priority conservation policies also take the opposite view of the participative model that has been professed [108, 109, 59]. In fact, there is also a lack of consensus on which human activities may be permitted in national parks in the case of occupation and use $[112,113,60$, 114] that paradoxically prevents any activity. In the case of political conflict and instability, social exclusion often serves as a pretext for uncontrolled occupation and significant destruction of protected areas by people fleeing war or seeking for new agricultural land $[115,111]$.

Because they are uninhabited, protected areas often constitute bastions, sanctuaries and rear bases for militias, guerrillas and rebellions that make them their guards, their training areas and their hiding places [111]. In the end, we observe that conservation policies balance between truly contradictory options, since internalization and appropriation of participatory management approaches are hindered by the technical and financial conditions of the large conservation NGOs and international donors that are "more and more closed" to "more and more open protected areas". This dilemma of the conservation in Africa is accompanied by instability in laws, statutes and field practices that increases frustration, stimulates social conflicts and further exposes protected areas to degradation by strategically and usefully repositioning actors at each new conservation initiative [20]. This is more evident in countries with limited resources where the fortress conservation approach is the most inefficient $[27,110]$.

In this context of policy inadequacy and of deep land tensions, the extension of protected area networks for the achievement of the Aichi Targets and the development of ecotourism especially in savannah areas in Southern and Eastern Africa further exacerbates the socio-economic precariousness of peripheral rural populations, especially since the financial crisis hardly makes it possible to finance at the same time the management of existing protected areas and the compensatory measures required for the new areas.

\subsection{Inadequate, Poorly Mastered and Inefficient Management Systems}

As already mentioned, the management of African protected areas is based on imported governance characterized by the ex-cathedra adoption of the principles and goals of protection decided at international level but which are unfortunately disconnected from the traditional mechanisms of management of shared natural resources [104]. This mode of governance articulated on a system of co-management of protected areas between States, conservation NGOs and/or international donors promotes the ecological interest of protected areas against the socioeconomic concerns of local populations which are often poor, heterogeneous and politically weak $[25,20]$. In most countries, the agencies responsible for the implementation of this kind of governance are usually associated with dominant ministerial structures and do not have the necessary administrative and financial autonomy to take initiatives and to achieve a management effectiveness that should be comparable to that of autonomous or semi-autonomous structures that have their own budgets and a sufficient administrative autonomy [18, 14].

Thus, African protected areas remain largely managed according to a centralized, authoritarian and bureaucratic vision of planned resource management [2]. In general, the laws do not set management goals, management plans and boundaries of protected areas of which some would only exist on paper and would be dangerously threatened $[14,25$, 
90]. In this respect, it is estimated that $85 \%$ of African protected areas have no management categories, goals and plans [16]. In cases where management plans exist, they are rarely validated, implemented, evaluated and updated [105].

In the majority of protected areas, these fundamental deficiencies are aggravated by four major physical constraints, namely: (1) the absence of precise boundaries that are materialized on the ground, (2) the absence of buffer zones defined by the theoretical concentric structure of protected areas for the absorption of peripheral social conflicts 43], (3) the asymmetric and irregular shapes that increase linear exposure and strengthen physical vulnerability to peripheral pressure [35] and (4) the geographic dispersion that often makes it difficult or impossible to build connective networks for easy biological migrations $[116,20]$. In cases where they exist, buffer zones are recovered for the extension of the protected areas of attachment, beyond the initial limits inherited from colonization. In practice, the management of the great majority of protected areas is a sight navigation that is characterized by improvisations and trials and errors that make it difficult to conclude strategic partnerships for conservation, the mobilization of funding and the assessment of the management efficiency.

On the African continent, there are generally significant gaps between conservationist rhetoric and actual management practices that remain largely unchanged, despite the good intentions of official policies and speeches $[25,20]$. These differences are expressed by sometimes glaring discrepancies between the management categories and the actual modes of management. For example, occupations and activities of authorized exploitations of natural resources corresponding to management category VI are often carried out in protected areas of management category IV $[117,20]$. In addition, management categories serve as pretexts to dispossess people of their lands when they are only indicative [80]. In this respect, national parks are still managed according to the guidelines or the international and normative definition of category II, which excludes any human activity other than research, education and tourism [76, 59].

As an illustration, the creation of national parks and the transformation of existing protected areas into national parks are continuously and still leading to population expulsions [20]. With regard to the accompanying measures of participatory approaches, also the reasoned zoning of national parks and the creation of multi-category networks for a minimal exploitation of resources are rare, so that the participatory management activities organized in protected areas of category II are conducted in violation of the normative management criteria. In any case, the dismemberment of national parks into networks of mini multi-category protected areas to promote participatory management, improve protection and control degradations cannot be effective in the long term, in African contexts. In fact, it constitutes a disguised admission of failure of sanctuary management that seeks to reproduce at a small scale what it has failed to achieve at a larger scale. In other countries, type A or state governance is abusively assimilated to co-management or participatory management systems while it is heavily administered and overseen by central governments.

From another angle, the lack or insufficiency of reliable research and databases jeopardizes the development and updating of conservation goals and management plans; which mortgages the necessary evolution and the efficiency of the management systems $[118,105]$. In many protected areas, the updating of the management plans does not rely on in-depth assessments of global evolutionary trends, due to the lack of appropriate technical tools and of human and financial resources [119, 43, 97]. Indeed, usual systems of brief and quick self-assessment like the "Management Effectiveness Tracking Tool for the Rapid Assessment and Prioritization of Protected Areas Management" (METT-RAPPAM) are poorly mastered and rarely applied.

On the continent, the lack of rigorous and credible assessment systems of the nature, processes and magnitude of spatial transformations affecting protected areas does not make it easy to formulate appropriate legislative, technical, financial and managerial responses to the management challenges. Chronic inadequacy and inappropriate management rules and tools often reinforce negative trends and lead to further degradation of protected areas, in the absence of buffer zones able to absorb peripheral pressure. Finally, management rules and systems have globally failed to maintain original situations of protected areas [105].

\subsection{Limitations and Weaknesses of Ecotourism Programs}

Since eco-tourism was presented as the great socioeconomic argument that could justify and legitimize the nature conservation in Africa, it has got very little impact in many countries $[56,25,20]$. Despite the spectacular evolution of nature, safari and culture tourism during the 2000 s, the continent remains one of the world's least popular tourist destinations. In 2011, Africa counted for only 5.1\% of the world's international tourist population. In general, the creation of local wealth based on tourism shows huge disparities between countries and regions. While tourism remains weak or quite inexistent in many protected areas in Western and Central French-speaking Africa, it is successful in a few English-speaking Eastern and Southern African states well-known for their protected areas [14].

Beyond the obvious negative influence of structural, organizational and strategic factors, political crises and instability explain the poor tourism performances of protected areas in some countries, particularly in Central Africa [20]. According to the World Bank, tourism receipts contribute only for $8.9 \%$ of Gross Domestic Product in East Africa; $7.2 \%$ in North Africa; 5.6\% in West Africa; 3.9\% in Southern Africa and 1\% in Central Africa. The revenues from the economic valuation of protected areas and tourism are mostly distributed on a macro-economic scale between foreign or national private companies, park management services and states [73].

They often remain an exchange between foreign tourists and external operators; so that the benefits generated by the 
tourism valorization go largely to the private sector $[56,66]$. Regarding domestic tourism, this one is quite inexistent because of the often negative perception of wild animals by populations, the high tariffs charged to national tourists, and the important costs associated to tourism like transportation and accommodation, compared to generalized low income and priorities survival. In the few countries where ecotourism and the distribution of tourist revenue are some successes, the tourist income is administered according to public rules and directed towards traditional development activities like the construction of schools and health centers that do not compensate the direct socio-economic losses and needs of local populations [120].

Moreover, official statements on the socio-economic benefits of tourism only announce the turnover generated by ecotourism activities and the usual proportion of 5 to $10 \%$ which is often offered to local communities to finance common development activities [66, 120]. Nothing is said about operating expenses, related tourism revenues, actual net profit, and the distribution of profits between stakeholders that is defined without the involvement of communities. This obviously raises the problem of relevance of participation, transparency in management, equity in benefit sharing and environmental justice, in short [120].

In most of cases, local communities involved in ecotourism projects would receive only a small share of the benefits and would depend only on other activities that are sometimes very predatory for their livelihood [113, 54, 56, $19,66]$. Except the sale of some handcraft products and lowpaid jobs by local staff such as tour guides, tourist baggage handlers, maids in hotels and car drivers, the economic benefits of tourism are derisory in Africa [19, 66, 20]. In many countries, the low income from ecotourism and wildlife related commercial activities and their retrocession to central services exclude or limit the socio-economic impacts on local populations and protected areas selffinancing $[14,20]$.

Ultimately, these developments show that the exaggerated expectations from countries and communities with respect to the socio-economic benefits of ecotourism are far from being met in most countries, regardless the tourism successes and failures at macro-economic level. They are mortgaged by the quasi-exclusive dependence of the sector on external tourism, which is largely dependent on political and security risks, the influence of profit-driven private companies and the growing imbalances in the sharing of conservation benefits with regard to local communities. The gradual decreasing of international funding, the weak national investments in nature conservation, the persistent human wildlife conflicts, and the lack of fair and equitable compensation for damages [1, 121-123], persistent insecurity and ongoing protected areas degradation are factors that do not promote positive tourism development in Africa. Indeed, well financed, secured and managed protected areas have a more interesting development of tourism and touristic incomes.

\subsection{Weak Performances and Inefficiency of Participatory Approaches}

If participatory management seeks to reintegrate local populations into the management of protected areas for the re-appropriation of lost profits, it is true that the initiative and the power of the organization of space and activities are still beyond their control [98, 124]. Actually, beyond the legislation that speaks about the interests of the populations, the management of many protected areas still remains under the protectionism approach for the capture of external financings that are more and more conditioned to the fortress conservation. In participatory partnerships for conservation, states still play a central role as it concentrates the ownership and the responsibility for the management of protected areas under co-management status [105].

This is the case in West Africa where the control of protected areas is often subject to conflicts between states and local communities [105]. Most often, local populations are only auxiliaries or relays for conservation who serve to diffuse unilateral management decisions, without having any prerogative $[125,25,126]$. Participation has simply become a way of legitimizing and validating decisions already made by protected area managers, in complete contradiction with theoretical principles of this decentralized and democratic management approach [127, 128, 89, 126, 34, 84]. In its current form, participatory management seems to involve local people to protect protected areas "against themselves" ultimately [20]. Finally, the real commitment of local populations and the community partnership for conservation are still weak $[25,20]$.

Despite the old introductions of the participatory paradigm and the legislative advances in this field $[60,2]$, the current management methods remain dominated by centralized and coercive practices $[68,8,105]$. This often appears through the determination of the methods for the resource exploitation, the definition of the tourism revenue sharing mechanisms and the choice of the community development investments that are, in any case, the responsibility of states, regardless of the presence of protected areas. Generally, participatory management regulations are only articulated on good principles that are part of the classic rhetoric of conservation because states often lack the means for the implementation of their policies [25].

While participatory management recognizes the land rights of indigenous peoples and the abandonment of forced displacements in the establishment and the management of protected areas [75], the violation of these rights has continued in the great majority of protected areas [129, 59]. When through the decentralization processes, certain transfers of powers and responsibilities become effective; they are quickly recovered by powerful groups of interests for their own benefit [25]. This means that the decentralization often generates a new centralization at a lower level, which perpetuates the same imbalanced powers, the same democratic deficits and the same negative effects [20]. The recurrent advisory role of local populations in the protected areas management does not yet 
allow to reverse trends and to engage a fruitful participation [25, 126-127, 84].

As a result, the social impact of conservation projects "for, with and by" communities based on direct and controlled exploitation of resources and the financing of incomegenerating activities by protected areas is insignificant in the majority of protected areas [14, 25, 130-131]. In addition to the very limited impacts of participatory management actions, participatory management programs are fundamentally unfair for two main reasons. Firstly, farmers pay dearly in work the access to previously owned natural resources through common participatory projects based on work against resources [77, 20]. Secondly, the real benefits from the exploitation of resources are largely captured by elites [66]. Actually, socio-economic opportunities related to participatory management are derisory with regard to local communities. They rely only on few local jobs of eco-guards, trackers and lodge staff, limited extractions of some nontimber forest products and little income-generating activities. In fact, the low level of operating revenues from protected areas and the retrocession of a large part to central conservation services do not allow to finance truly incomegenerating activities and to create consistent jobs for local populations $[77,20]$.

In summary, the main factors that limit the effectiveness of participatory management are: (1) internal contradictions and conflicts of interest between stakeholders that are generally heterogeneous $[132,25]$, (2) the current incompatibility between the exploitation of resources and conservation goals due to lack of prior or accompanying research [20], (3) the frustrating position of landless people who often serve as workforce for wealthy and powerful individuals in participatory management projects [25], (4) the highly restrictive conditions for the sustainable use of natural resources through various mechanisms of regulation of extractions and the high taxation of products $[52,20],(5)$ the anecdotal and symbolic nature of local job opportunities and access to resources in comparison with the immense socioeconomic needs of peripheral populations $[77,133]$, (6) the weaknesses of net operating revenues compared to the great profitability of non-sustainable management activities [69, 54, $125,25,131],(7)$ the inability of participatory management programs to respond to external forces that threaten protected areas such as the attractiveness of migrants, the degradation induced by successful projects and the short duration of the projects [134], (8) the determining role of territorial administrations in the creation and the management of the abusively named communitarian protected areas [77], (9) the underfunding of participatory management projects for protected areas whose major threats come from powerful and external economic interests and projects [61] and (10) the incoherence between common participatory management and the principles of conservation marketing, particularly with regard to the socio-economic equity and the maximalist trade profits [135].

In conclusion, it is the dilemma between ideological alignment to participatory policies and the contradictory concern of capturing external funding that are highly conditioned by fortress conservation that would explain the obvious limits, or even the failure of participatory programs. The lack of self-financing and the heavy reliance of protected areas on external funding constitute a death sentence for participatory approaches that are no longer favored by conservationist actors and international donors. Unable to self-finance and fund local development that supports participatory management, African protected areas often have no other choice than to comply with the requirements of the major international conservation NGOs and donors who are again interested by sanctuary management in tropical areas. Therefore, the comeback of fortress conservation approaches, the low impact of participatory projects and the proven limits of ecotourism for the compensation of the loss of direct access to natural resources show that the conservation sector in Africa is in crisis and needs to be rethought on new bases.

\subsection{Funding Structural Crises, Prioritization and Selectivity}

In Africa, the conservation sector is characterized by low budgets and chronic underfunding that hinder the effectiveness of the protected areas management. With annual average budgets reaching hardly 5 US\$ /ha/year [72, 20], it remains one of the neglected sectors in African economies despite the enormous interests that it represents and the challenges it faces. Despite the generalized insufficiency of conservation budgets, huge disparities exist between countries. National conservation budgets range from a few thousand to a few million US dollars [136, 20]. Studies have shown that most African countries devote less than $20 \%$ of the amount considered as appropriate to national park management $[135,37,1]$. They indicate that the investment per $\mathrm{km}^{2}$ in US national parks is 6 times higher than in Central Africa, despite a much lower biodiversity [61].

The weakness of national conservation budgets, the inability of protected areas to generate enough revenue through tourism and exploitation of resource, the return of most of the operating revenue to central services and the high dependence on external financings that becomes uncertain explain the ineffectiveness and the inefficiency of conservation policies [137, 43, 61]. In African countries, the cuts of budget that are common to protected areas are unfortunately increasing in times of political conflicts and crisis; precisely when they face widespread destructive assaults $[137,83,56,20]$. This politico-financial paradox is prejudicial to protected areas and conservation because the times and conditions of high vulnerability occur simultaneously. The low capacity for internal and external financial mobilization which is common to many protected areas results from the lack of financial planning and the multiple challenges of tourism that are driven by conflicting interests [56, 73].

Unlike Western countries where protected areas operate on the basis of state budgets and the reinvestment of revenues from private exploitation through state representatives at the central, deconcentrated and decentralized levels [137], 
African countries have symbolic state funding and almost inexistent private contributions. Similarly, the funding mechanisms based on the public and private partnerships and the reinvestment of funds generated by protected areas in conservation are still marginal. The extension of protected areas networks and the cuts of budget in state subsidies are leading many protected areas in huge financial difficulties $[83,16]$, as much as international financial donors like the Global Environmental Facility (GEF) and the Trinity of Conservation (WWF, TNC, CI) allocate the available funds by prioritizing the so-called priority protected areas to secure their financing outside state frameworks [131].

Since Rio Conference in 1992, international funding is focused on the differential and preferential ecological interest of protected areas and countries [37]. Today, international conservationist currents and lobbies exchange funds against the maintenance and the multiplication of protected areas with sanctuary management. In fact, only the major international conservation NGOs are able to implement the new regional policies of priority conservation zones because of their prohibitive costs that are unaffordable to many other national and local actors [19]. The global triage policy in conservation that favors areas of maximum diversity and reduced vulnerability has limited or canceled the funding of many protected areas of lower priority with regard to the great threatens they are facing [1].

This selective policy was reinforced with the Digital Observatory of Protected areas (DOPA) initiative that manages protected areas larger than $100 \mathrm{~km}^{2}$, mainly in Africa [138]. Under this initiative, the allocation of funds gives priority to protected areas requiring greater attention and countries with the greatest potential in relation to agreed or decided global conservation goals, including the most recent Aichi conservation objectives [139]. At the same time, the extension of African protected areas networks and the affirmation of participatory management approaches lead to a reduction in the availability of international funding on which most of countries rely, including for the funding of regional conservation institutions that are gradually emerging in Africa [66]. The GEF which is the largest international mechanism for conservation funding, provides only punctual and unforeseeable contributions due to equally timely contributions from its financial supports $[43,56]$.

In addition to being unpredictable, external funding often only covers protected areas research and management activities, while being limited by the duration of specific projects $[43,20]$. In this context of international financial crisis; the high dependence of African protected areas on external financing and the enormous selectivity of zones and protected areas that are eligible to financings, the question of financial planning, self-financing and empowerment becomes a particular concern [56]. In the absence of sufficient budgets and financial autonomy, national conservation organizations are unable to conserve funds raised in protected areas [137, 43]. They are also not encouraged to develop revenuegenerating programs that they are obliged to hand over to the public treasury, or to cooperate with the private sector. Under these conditions, participatory management projects receive only small conservation grants for emergency management and short-term actions, especially in protected areas of categories IV and VI [105, 140].

In practice, the selectivity of priority conservation areas and of the external financing of conservation in Africa is accompanied by equally preferential external tourism that is successful in well-funded and managed protected areas of some countries. In the end, this generates an external conservation for an external consumption that does not allow national and local bodies to play a fruitful role in protected areas management. Since they have no autonomous means to implement their policies, they are obliged to comply with the policies and programs of those who finance them.

\section{Ideological Challenges and Bottlenecks for Nature Conservation}

The in-depth critical analysis of the governance systems of the conservation in Africa shown that the ongoing conditions of the protected areas management are responsible for a systematic, increasing and continuous degradation that makes many protected areas open agricultural and agropastoral parks under a protection status that only exist on paper. It revealed that the major bottlenecks and challenges to be addressed are the following: (1) the still dominant model of uninhabited protected areas in a context of high population densities and deep land tensions, (2) the lack of compensation and relocation of populations expelled from protected areas that leads to the concentration of these people at the immediate peripheries of protected areas, (3) the absence, narrowness or non-functionality of buffer zones for a minimum socio-economic compensation of imposed deprivations, (4) the persistence of centralized and coercive management methods, insufficient guarding staff and increased illegal agropastoral pressures, (5) the chronic internal underfunding and unreliable external financing, (6) the quite inexistent domestic tourism, and the limited socioeconomic benefits of ecotourism and of activities of exploitation of resources, (7) a lack of data, tools and indicators for planning and management that lead to sight navigations and trials and errors in management, (8) democratic and managerial deficits in participatory management, and unequal distribution of the conservation benefits in the disfavor of local populations, (9) the persistence of human-wildlife conflicts and the lack of effective and equitable economic compensation systems and (10) the instability of conservation statutes and the proliferation of concessions of economic exploitation for the benefit of external private investors.

The management challenges result from a certain number of interferences, incoherence, contradictions, ambiguities and misunderstandings that the new vision for a fair and sustainable conservation will address. Firstly, the primacy of external institutions and actors in the choice of the main areas to be protected or kept under protection, the definition of 
conservation policies and practices, the financing of protected areas and the growth of tourism makes conservation an interested external business that is often disconnected from basic socio-economic concerns and needs of local populations. Secondly, the world conservation enterprise conveys now a fundamental contradiction or hypocrisy that recognizes and theoretically promotes the interests and know-how of local people, while effectively making them passive and marginalized partners in accessing the benefits of the conversation. Thirdly, the coming in of private investors devotes capitalist practices that further marginalize local communities in management and fair access to conservation benefits. Fourthly, the easy neoMalthusian argument about the negative impact of the population growth on the exploitation of natural resources obscures the social exclusion and inequalities of access to natural resources as the main causes of exploitation pressure and degradation. Fifthly, the current coverage of illegal activities and demands by local governments and political elites for political purposes is frustrating protected areas managers and deserving the cause of conservation. Sixthly, the lucrative illegal or legal exploitations of protected areas by wealthy and powerful individuals using poor local populations as labor deconstruct the universal interests and benefits of conservation. In fact, African protected areas are more threatened by powerful economic interests carried by large agribusiness projects than by the survival resources extractions of local populations. Seventhly, the quasigeneralized democratic deficits in African countries and the persistence of top down approaches do not allow a truly democratic management of natural resources required by participatory approaches. Since the community participation is often decided by governments, in its forms and modalities, it cannot create and guarantee genuine community membership in conservation. Actually, the current conditions of the protection of tropical natural areas ensure an indirect and uncompensated international re-appropriation of national and communitarian resources that is made possible by the substitution of citizen awareness by reinforced state control and constraints for more and more sanctuary management. In practice, the forced or induced exploitation pressures reflect an open protest to the violation of multi-secular and legitimate socio-economic interests of the local populations; particularly with regard to access to plant resources for domestic energy and to cropland and pasture land. They constitute real denials for conservation that is currently experiencing a systematic and accelerated degradation of protected areas. In the following lines, we develop the major articulations of a new vision for coherent, equitable, inclusive and sustainable management of protected areas in Africa.

\section{Strategic Vision and Options for Sustainable Conservation}

The strategic vision and options proposed to address management challenges and ensure broadly inclusive, mutually beneficial and sustainable conservation of protected areas in Africa are built on the key results emerging from the critical analysis of conservation policies and practices namely, (i) conservation involves multiple actors with conflicting interests, unbalanced powers and unequal means of intervention, (ii) community-based and traditional nonmarket management of natural resources are the most effective and sustainable forms of conservation, (iii) the substitution of "man in nature" by "man and nature" made possible by the strengthening of fortress approach and the weaknesses of participatory approaches are the major ingredient of the hostility of populations and the main driver of degrading pressures, (iv) the establishment of many largescale protected areas maintained outside the sphere of socioeconomic action contribute to create stresses and to reinforce illegal pressures, (v) the lack of fair, equitable and timely compensation for expropriations and deprivations still justifies illegal loggings and degradation of protected areas, (vi) the international and national benefits of ecosystem services provided by protected areas inevitably result from direct losses of benefits for local communities that are not at all or not enough compensated, (vii) the ineffectiveness of the fortress conservation approach and the low efficiency of participatory programs are based on many factors that are external to local communities, (viii) the decentralization in natural resources management actually leads to a low-level centralization that perpetuates the state's diktat and the imbalanced powers in disfavor of local populations, (ix) the interest of conservation for local populations and national governments is generally perceived through direct socioeconomic benefits and financial support or income and $(\mathrm{x})$ the achievement of the Aichi goals for the extension of protected areas networks is compromised by deep land tensions, large-scale community opposition and significant financing difficulties.

The options proposed to achieve sustainable conservation are based on eight fundamental principles: (1) the effectiveness of conservation has to be thought and assessed as a balance between the achievement of global ecological and economic goals and the satisfaction of vital socioeconomic needs of local communities, (2) sustainable conservation approaches should guaranty a minimum access to vital natural resources or alternative fair, equitable and sustainable socio-economic compensation in the case of exceptional sanctuary conservation, (3) efficient conservation approaches have to rely on community commitment and responsibility for conservation instead of individual or associative involvements of persons considered in local communities, (4) genuine and active participation of local communities in management mechanisms and conservation benefit sharing have to rely on broadly representative and democratic bases, (5) decision making and powers involved in conservation partnerships have to be rebalanced in favor of local communities through a democratic and sufficient representation of communities in administrative and management bodies, (6) the management bodies have to be administratively and financially autonomous for each 
protected area, (7) the sustainable financing of conservation and the efficiency of conservation have to rely mainly on the development of domestic tourism and on internal resources and (8) the financing of socio-economic compensations and continuous protected areas management have to be based on international and national citizen awareness and solidarity for the safeguarding of ecosystem services which are also of universal interests and profits.

The vision defends the reproduction, the modernization and multi-level financing of community-based conservation known to be a successful approach of conservation, while adapting it to current realities. At ideological, strategic and operational levels, the new options are as follows: (i) the replacement of the concept of protected areas that conveys a strongly homophobic connotation by the more neutral but evocative concept of "biodiversity conservation areas", (ii) the systematic and prior evaluation of the management of existing protected areas for the characterization of spatial transformations and landscape dynamics, the identification of the global evolutionary trends and their classification taking into account the degree of threats and degradation, (iii) the transformation of highly degradated or threatened protected areas into natural communitarian landscapes to be managed according to the principles of agro-ecology and to concerted conventions of conservation management, (iv) the priority allocation of financial savings, available resources and funding mobilized to the management of protected areas with positive evolutionary trends or enough stability for the development of peripheral sustainable projects and ecologically connective networks, (v) the focus of conservation on the paradigms of 'protection through production' and 'production through protection' based on the development of peripheral compensatory projects oriented towards agro-pastoral modernization and intensification and energy substitutions thanks to universal compensatory funds and socio-economic benefits of conservation, (vi) the delimitation of peripheral socio-economic dependent zones and the democratic establishment of autonomous community councils representing different groups of interests for protected areas active management, (vii) the establishment of state-local communities-private joint shareholdings and autonomous protected area boards of directors composed of the representatives of stakeholders and notably intended to vote programs and operating budgets, to define periodic extractions of resources that are essential for vital socioeconomic uses, to adopt accounts and management reports, to decide on the allocation of operating profits, to endorse community development projects that support conservation and to update management objectives, plans and tools, (viii) the establishment of national environmental pilgrimages for the development of patriotic mass tourism relying on the principle of proximity, community-based logistics and affordable tariffs, (ix) the establishment of universal national and international funds to finance compensatory projects and actions for short and long terms socio-economic deprivations and damages by wild animals and permanent management of protected areas in return for the universal and "eternal" benefits of ecosystem services; and (x) the focus of the Aichi conservation goals on the establishment of natural communitarian and inhabited landscapes, with respect to terrestrial networks.

In concrete terms, national universal funds would consist of single, compulsory and solidarity-based citizen contributions. A part of the funds would finance initial compensatory projects for agropastoral modernization and energy substitutions in the peripheries of protected areas, another one the community shareholding for a lasting compensation of long term deprivations and permanent socio-economic damages by wildlife, the self-sustaining individual and community development projects, and the financial and administrative autonomy of community conservation councils and the balance, the public shareholding and its permanent contribution to the conservation programs. Regarding the universal international fund, it would be created for the compulsory compensating financing of protected areas of international importance. It would consist of country contributions that could be defined on the basis of their carbon footprints. The annual differential funding of the protected areas eligible for this international solidarity would for example depend on their specific wealth, their extents, their carbon sink capacity and their transboundary character.

\section{Conclusion}

The critical retrospective analysis of the policies and practices of nature conservation in Africa showed that they are characterized by a certain number of incoherence, inconsistencies, contradictions and ambiguities that lead to inefficient management and serious challenges for sustainable conservation of protected areas. It revealed that the governance systems are creating management conditions that favor uncontrolled exploitations and almost systematic and continuous degradation of protected areas of which the majority have become open agropastoral parks, under legal protection status. Since the colonial period, the conservation governance has globally failed to achieve and maintain a minimum of efficiency in the management of protected areas. The study showed that poor performance and continuous degradation of protected areas are mainly justified by conflicts of ideologies, interests, and agendas between multiple actors having imbalanced means of intervention, positions and powers. Beyond the financing difficulties and obvious technical and managerial gaps, the main challenges that the sector of conservation is facing are the important role played by external bodies and actors, democratic deficits and the persistence of centralized approaches at the national level, the ambiguity of territorial administrations and political elites in their relations with local communities regarding conservation actions, the interferences and capitalist activities of external economic operators, the weakness of the participatory management approaches and the marginalization of the local communities in protected areas management and access to the socio-economic benefits of the conservation. The vision 
proposed to address the conservation challenges considers and evaluates the conservation effectiveness as a balance between the satisfaction of vital non-market community socioeconomic needs and the achievement of global ecological and economic goals through compensatory market preservation. Its starting point is the preliminary assessment of the evolutionary trends of protected areas for an in depth rethinking and restructuration of the conservation statutes and the management categories, the conservation partnerships, the modes of administration and management and the financing modalities. It fundamentally refocuses conservation on community interests, commitment, responsibility and participation, a rebalancing of forces and powers in the partnerships, the institution of State-Local communitiesPrivate joint shareholdings, the universal solidarity financing of socio-economic compensations and permanent management of protected areas and equitable sharing of socio-economic benefits. In practice, it involves a well thought revision and the improvement of the management based on strategic decommissioning and reclassifications of existing protected areas, and the extensions of protected areas networks centered on local communities.

\section{References}

[1] Colchester M. (2003). Nature sauvage, nature sauvée? Peuples autochtones, aires protégées et conservation de la biodiversité. Mouvement mondial pour les forêts tropicales, (WRM) et Fonds mondial pour la nature (WWF), 154p.

[2] Giraut F., Guyot S. et Houssay-Holzschuch M. (2004). Les aires protégées dans les recompositions territoriales africaines. L'information géographique, Armand Colin, p. 340-368. $<$ Hal-00185681>.

[3] Kabore A. (2010). Brousse des uns, aire protégée des autres. Histoire du peuplement, perceptions de la nature et politique des aires protégées dans le Gourma burkinabè: l'exemple de la Réserve partielle de faune de Pama. Thèse de Doctorat. Institut de Hautes Etudes Internationales (Genève) et du Développement pour l'obtention du grade de Docteur en études du développement, 397p.

[4] Kasisi R. (2012). Les perspectives de la biodiversité en Afrique subsaharienne: repenser collectivement le modèle de gestion. Vertigo-la revue électronique en sciences de l'environnement, vol. 12, $\mathrm{n}^{\circ}$ 2, [En Ligne]; URL: http://vertigo.revues.org/12263; DOI: 10.4000/vertigo.12263.

[5] WWF/BAD (2012). Rapport sur l'Empreinte Ecologique de l'Afrique, $72 \mathrm{p}$, www.protectedplanet.net consulté le 21/12/2016.

[6] MEA (2005). Rapport de synthèse de l'Evaluation des Ecosystèmes pour le Millénaire. Millenium Ecosystem Assessment, 59p.

[7] Dudley N., Stolton S., Belokurov A. and al. (2010). Natural solutions: Protected areas helping people cope with climate change. Gland (Switzerland), Washington DC and New York (USA): IUCN-WCPA, TNC, UNDP, WCS, The World Bank, WWF, 130p.

[8] Fonds pour l'Environnement Mondial (2010). Approche-
Programme pour la préservation de la biodiversité en Afrique de l'Ouest et en Afrique centrale, 32p.

[9] McCarty J.P. (2001). Ecological consequences of recent climate change. Conservation Biology, 15: 320-331.

[10] Welch D. (2005). What should protected area managers do in the face of climate change? The George Wright forum, 22: 7593.

[11] Hopkins J. J., Allison H. M., Walmsley C. A. and al. (2007). Conserving Biodiversity in a Changing Climate: guidance on building capacity to adapt, Department of Environment, Food and Rural Affairs, London, 32p.

[12] Rodary E. (2001). Les espaces naturels: l'aménagement par la participation? Mise en réseau et territorialisation des politiques de conservation de la faune en Zambie et au Zimbabwe. Thèse de Doctorat, Université d'Orléans, France, $531 \mathrm{p}$.

[13] Rodary E., Castellanet C. et Rossi G. (dir.) (2003). Conservation de la nature et développement. L'intégration impossible ? Paris, GRET, Karthala, 308p.

[14] Triplet P. (2009). Manuel de Gestion des Aires Protégées d'Afrique Francophone, 1250p.

[15] Dumoulin D. K. et Rodary E. (2005). Les ONG, au centre du secteur mondial de la conservation de la biodiversité. In Aubertin C. (éd.): Représenter la nature ? ONG et biodiversité, Paris, IRD Éditions: pp 59-98.

[16] Deguignet M., Jufe-Bignoli D., Harrison J. et al. (2014). Liste des Nations Unies des Aires Protégées 2014. UNEP-WCMC: Cambridge, UK, 44p.

[17] Ndemanou R. (2012). La problématique de gestion des aires protégées en Afrique Centrale: le cas du Parc National de la Lopé au Gabon, Yaoundé, Réseau ECOFAC, 34p.

[18] Rwanyiziri G. (2009). Géopolitique de l'environnement au Rwanda. Pour une gouvernance participative des espaces protégés. Geography, Université de Pau et des Pays de l'Adour (France). Thèse de Doctorat, 477p. HAL Id: tel-00449865 https://tel.archives-ouvertes.fr/tel-00449865.

[19] Aubertin C. et Rodary E. (2008). Aires protégées, espaces durables? IRD, 276p.

[20] Ntiranyibagira E. (2017). Dynamiques d'occupation du sol, tendances évolutives globales et facteurs d'evolution des aires protégées. Etude diachronique du Parc national périurbain de la Rusizi (Burundi) de 1984 a 2015. These de Doctorat Unique en Sciences de l'Environnement, Université Cheikh Anta Diop de Dakar (Senegal), 340p.

[21] Convention on Biological Diversity (2011). Protected Areas: Progress in the implementation of the Program of Work and achievement of Aichi Biodiversity Target 11. $\mathrm{UNEP} / \mathrm{CBD} / \mathrm{COP} / 11 / 26$.

[22] Montpetit S. (2013). Les aires protégées transfrontalières: audelà de la conservation de la biodiversité. Essai pour l'obtention du grade de Maîtrise en Ecologie internationale, Université de Sherbrooke, 101p.

[23] Neumann R. P. (1998). Imposing Wilderness: struggles over livelihood and nature preservation in Africa, Los Angeles and Berkeley: University of California Press, 268 pp. 
[24] Descola P. (2008). A qui appartient la nature ? Texte paru dans laviedesidees.fr, $11 \mathrm{p}$.

[25] Binot A. (2010). La Conservation de la Nature en Afrique Centrale. Entre Théories et Pratiques. Des Espaces Protégés à Géométrie Variable. Thèse de Doctorat, Université Paris 1 Panthéon-Sorbonne, 444p.

[26] Williams M. (2000). Dark ages and dark areas: global deforestation in the deep past. Journal of Historical Geography, 26: $28-46$.

[27] Raven P. H., Berg L. R. and Hassenzahl D. M. (2008). Environment, $6^{\text {th }}$ Edition, Wiley. Edition De Boeck Université pour la traduction et l'adaptation française, $687 \mathrm{p}$.

[28] Barima S. S. Y. (2009). Dynamique, fragmentation et diversité végétale des paysages forestiers en milieux de transition forêtsavane dans le Département de Tanda (Côte d'Ivoire). Thèse de Doctorat, Université Libre de Bruxelles, 196p.

[29] Bamba I. (2010). Anthropisation et dynamique spatiotemporelle de paysages forestiers en République Démocratique du Congo. Thèse de Doctorat, Université Libre de Bruxelles, 205p.

[30] Bogaert J., Barima Y. S. S., Iyongo W. M. L. and. (2011). Forest fragmentation: causes, ecological impacts and implications for landscape management. In Landscape Ecology in Forest Management and Conservation: Challenges and Solutions for Global Change, Li C, Lafortezza R, Chen J, (eds). HEP-Springer: New York, 273-296.

[31] Calas B. (2003). Quel est le véritable patrimoine des parcs animaliers est-africains ? In Patrimoine et développement dans les pays tropicaux, Pessac: DYMSET (Espaces Tropicaux, 18: 333-342.

[32] Rossi G. (2000). Ingérence écologique. Environnement et développement rural du Nord au Sud. CNRS Editions Coll. Espaces et Milieux, Paris, 248p.

[33] De Fries R., Krithi K. K. and Pareeth S. (2010). Interactions between protected areas and their surroundings in humandominated tropical landscapes; Biological Conservation, December 2010, 143 (12): 2870-2880.

[34] Veyret Y. (2012). Dictionnaire de l'Environnement, Paris, Armand Colin, 403p.

[35] Ntiranyibagira E., Naramabuye, F. X., Uwilingiyimana, T., Muhirwa, F. Kibogo, A., Umuziranenge, G., Kayumba I. and Nsengumuremyi, C. (2019). Design, Characterization and Geospatial Analysis of Physical and Socio-economic Indicators of Anthropogenic Pressures on Protected Areas in Africa. International Journal of Environment and Climate Change, 9 (1): 44-57, 2019; Article no. IJECC. 2019.004 DOI: 10.9734/IJECC/2019/v9i130096, ISSN: 2231-4784 (Online).

[36] Ramade F. (1981). Ecologie des ressources naturelles. Paris, Masson, 322p.

[37] IUCN (1999). Parks for biodiversity: policy guidance based on experience in ACP countries. Prepared by the World Commission on Protected Areas (WCPA) of IUCN. Brussels and UICN, Gland, Switzerland and Cambridge, U. K, 124p.

[38] Pèlerin E., Mansion A. et Lavigne Delville P. (2011). Afrique des Grands Lacs: droit à la terre, droit à la paix. Des clés pour comprendre et agir sur la sécurisation foncière rurale, Coll. Études et Travaux, série en ligne $\mathrm{n}^{\circ} 30$, Coéditions CCFD-
Terre Solidaire / GRET, www.gret.org, 127 p.

[39] Rwanyiziri G. (2002). Populations et aires protégées en Afrique de l'Est (Burundi, Kenya, Ouganda, Rwanda, Tanzanie). Mémoire présenté à l'Université Michel de Montaigne-Bordeaux III en vue de l'obtention de DEA en Géographie, 129p.

[40] Huxley J. (1961). The conservation of wildlife and natural habitats in Central and East Africa, UNESCO, Paris, 131p.

[41] Myers R., Mittermeier R. A., Mittermeier C. G., Da Fonseca G. A. B. and Kent J. (2000). Biodiversity hotspots for conservation priorities. Nature, vol. 403: 853-858.

[42] Harroy J. P. (1949). Afrique, terre qui meurt. La dégradation des sols africains sous l'influence de la colonisation. Bruxelles: Editions Marcel Hayez, 557p.

[43] Mengue-Medou C. (2002). Les aires protégées en Afrique: perspectives pour leur conservation. Vertigo [en ligne, la revue électronique en sciences de l'environnement]. 2002, vol. 3 , $\mathrm{n}^{\circ} 1, \quad$ avril 2002, 19p, Disponible sur http://vertigo.revues.org/index4126.html

[44] Rossi G. (2002). Ecologie du Nord, paysans du Sud: environnement et développement rural. Paris, CNRS Ed, $324 \mathrm{p}$.

[45] Turnbull C. (1987) Les Iks: survivre par cruauté. Nord Ouganda. Paris: Plon /Terre humaine, 389p.

[46] Constantin F. (1994). L'homme et la nature: une gestion à réinventer? In Politique africaine. Paris, Karthala, $\mathrm{n}^{\circ}$ 53, 3-10

[47] Péron X. (1995). L'occidentalisation des Maasaï du Kenya: privatisation foncière et destruction sociale chez les Maasaï du Kenya. Paris: L'Harmattan, 324p.

[48] Cochet H. (2001). Crises et révolutions agricoles au Burundi. Editions Karthala/INAPG, Paris, 468p.

[49] Sournia G. (1996). Les aires protégées d'Afrique francophone (Afrique centrale et occidentale). Hier, aujourd'hui, demain. Espaces à protéger ou espaces à partager ? Thèse de doctorat, Bordeaux, Université de Bordeaux III, 302p.

[50] Raffin J. P. (2005). De la protection de la nature à la gouvernance de la biodiversité. Ecologie et Politique, 97-109.

[51] IUCN, (1992). Protected areas of the World: a review of national systems. Volume 3: Afrotropical. Prepared par World Conservation Monitoring Centre. UICN, Gland, Switzerland and Cambridge, U. K, 360p.

[52] UICN, PNUE et WWF (1980). Stratégie Mondiale de la Conservation. La conservation des ressources vivantes pour le développement durable, Gland, UICN, 64p.

[53] TEEB (2010) L'Économie des écosystèmes et de la biodiversité: intégration de l'économie de la nature. Une synthèse de l'approche, des conclusions et des recommandations de la www.unep.org/pdf/TEEB_FR.pdf.

[54] Nicholls H. (2004). The Conservation Business, PLoS Biology, Vol. 2 (9): 1256-1259.

[55] Adams M. A., Aveling R., Brockington D. and al. (2004). Biodiversity Conservation and the Eradication of Poverty. Science, 306 (5699): 1146-9. 
[56] Dumoulin D. K. (2005). Les politiques de conservation de la nature en Amérique latine: au cœur de l'internationalisation et de la convergence des ordres politiques, IUED-NCCR NorthSouth (Genève) et CREDAL (Paris), REVISTA DE LA CEPAL • Numéro Spécial: 71-85.

[57] Hannah L. (1992). African people, African parks: an evaluation of development initiatives as a means of improving protected conservation in Africa. USAID, Washington, D.C., $76 \mathrm{p}$.

[58] Nelson A. and Chomitz K. (2009). Protected Area Effectiveness in Reducing Tropical Deforestation: A global analysis of the impact of protection status. Independent Evaluation Group, Evaluation Brief 7. The World Bank, Washington, D.C, 42p.

[59] Manuel B. et Doumenge C. (2008). Entre marginalisation et démagogie: quelle place reste-t-il pour les communautés locales dans les aires protégées ? Les Cahiers d'Outre-Mer [En ligne], $244 \mid$ 2008, mis en ligne le 01 octobre 2011, consulté le 01 décembre 2012. URL: http://com.revues.org/5476; DOI: 10.4000/com.5476, p 459488.

[60] Hulme D. and Murphree M. W. (ed.) (2001). African wildlife and livelihoods: the promise and performance of community conservation. James Currey, Oxford, UK, pp 336.

[61] Guéneau S. et Franck J. (2004). Conservation de la biodiversité forestière tropicale en Afrique centrale: dépassionner les débats. Institut du développement durable et des relations internationales. Idées pour le débat $n^{\circ} 14 / 2005$ Ressources naturelles, $11 \mathrm{p}$.

[62] Olson, D. M. and Dinerstein E. (2002). The Global 200: priority ecoregions for global conservation. Annals of the Missouri Botanical Garden, 89: 199-224.

[63] Wes S., Brooks T. M., Da Fonseca G. A. B. and al. (2002). Hotspots and the conservation of evolutionary history. Proc Natl. Acad. Sci. USA, 99 (4): 2067-2071. DOI: 10.1073/pnas. 251680798

[64] Brooks T. M., Mittermeier R. A., Da Fonseca G. A. B. and al. (2006). Global biodiversity conservation priorities, Science, 313: 58-61.

[65] Vives, M. (2001). Les aires protégées: un arc à plusieurs cordes, Canopée $\mathrm{n}^{\circ} 20$, juin 2001

[66] Doumenge C., Palla F., Scholte P., Hiol F. et Larzillière A. (2015). Aires protégées d'Afrique centrale - État 2015. OFAC, Kinshasa, République Démocratique du Congo et Yaoundé, Cameroun, $256 \mathrm{p}$.

[67] Ferraro P. J. and Kiss A. (2002). Getting what you paid for: direct payment an alternative investment for conserving biodiversity, Science ${ }^{\circ}$ 268, November 29, 2002.

[68] Brown K. (2003). Three challenges for a real people-centred conservation, Global Ecology and Biogeography, 12: 89-92

[69] Ferraro P. and Simpson D. (2003). Protecting forest and biodiversity: Are investments in eco-friendly production activities the best way to protect endangered ecosystems and enhance rural livelihoods? Paper presented at the international conference on Rural Livelihoods, Forests and Biodiversity, 5 (2): $167-181$.

[70] Emerton L., Bishop J. and Thomas L. (2006). Sustainable
Financing of Protected Areas. A global review of challenges and options. Best Practice Protected Area Guidelines Series No. 13. IUCN: Gland, Switzerland and Cambridge UK, 109p.

[71] Smith J. (2013). Gestion et financement des aires protégées pour leur adaptation au changement climatique: Une analyse rapide des possibilités. UNEP-WCMC rapport technique, $61 \mathrm{p}$.

[72] Carret J-C. et Loyer D. (non daté): Comment financer durablement le réseau d'aires protégées terrestres à Madagascar ? Apport de l'analyse économique. Banque Mondiale, Agence Française de Développement, 12p.

[73] Landreau B. (2012). Guide pour l'élaboration des Plans d'Affaires simplifiés pour les Aires Protégées. Fédération Internationale du Banc d'Arquin (FIBA). Agence Française pour le Développement (AFD), Fonds Français pour l'Environnement Mondial, 61p.

[74] Depraz S (2008). Géographie des espaces naturels protégés. Genèse, principes et enjeux territoriaux. Paris: Armand Colin, 320 p.

[75] Convention sur la Diversité Biologique (1992). Convention sur la diversité biologique. Rio de Janeiro, ONU, 32p.

[76] UICN (1994). Lignes directrices pour les catégories de gestion des aires protégées. Commission des parcs nationaux et des aires protégées de l'Union mondiale pour la nature, avec l'assistance du Centre mondial de la surveillance continue de la conservation. $102 \mathrm{p}$.

[77] Granier L. (2009). Participation des populations locales à la gestion des aires protégées et contribution à la lutte contre la pauvreté: de nouvelles solutions juridiques, http://www.ecocy.net/fr/journal.php?actu=29 consulté le $15 / 03 / 2015,3 p$.

[78] Convention sur la Diversité Biologique (2004). Programme de Travail sur les Aires Protégées. Montréal: Secrétariat de la Convention sur la diversité biologique, 34p.

[79] Héritier S. (2007). Les parcs nationaux entre conservation durable et développement local. Géocarrefour [En ligne], Vol. 82/4 2007, mis en ligne le 06 juin 2008, consulté le 10 octobre 2012. URL: http://geocarrefour.revues.org/2992, 6p.

[80] Dudley N. (2008). Lignes directrices pour l'application des catégories de gestion aux aires protégées. UICN, Gland, Suisse, $116 p$.

[81] Mahamadou S. M. et Boureima A. (2015). Indicateurs de mesure de la pression anthropique sur les ressources naturelles: exemple de la périphérie du Parc " W » dans la commune rurale de Tamou au Niger. Vertigo-la revue électronique en sciences de l'environnement, vol. 14, $\mathrm{n}^{\circ} 1$, http://vertigo.revues.org/14754.

[82] Tardif G. (1999). Mesures à privilégier en bordure des aires protégées au Québec pour contribuer à l'atteinte de leurs objectifs. Gouvernement du Québec, Ministère des Ressources naturelles, Rapport d'Expertise, 113p.

[83] Hugh S. (2000). Aires Protégées. Avantages sans frontières. La CMAP en action, UICN/CMAP, rue Mauverney 28, CH1196 Gland, Suisse. 19p.

[84] Borrini-Feyerabend G., Dudley N., Jaeger T. and al. (2013). Governance of Protected Areas: From understanding to action. Best Practice Protected Area Guidelines, Series 20, Gland, Switzerland: IUCN, xvi, 124p. 
[85] UICN (2004). Déclaration de Bangkok sur la gouvernance des ressources naturelles pour la conservation et le développement durable. Bangkok, $4 \mathrm{p}$.

[86] Nouidemona J. D (2004). La problématique des activités humaines dans les aires classées: Cas du Parc National du Delta du Saloum (Sénégal). Mémoire de DEA. Université Cheikh Anta Diop de Dakar, Institut des Sciences de l'Environnement, 95p.

[87] Mackinnon J. K., Mackinnon G. C et Thorsell J. (1990). Aménagement et gestion des aires protégées tropicales, UICN, Suisse, $307 \mathrm{p}$.

[88] Chiffaut A. (2006). Guide méthodologique des plans de gestion de réserves naturelles. MEED/ATEN, Cahier technique $\mathrm{N}^{\circ} 79: 72 \mathrm{p}$.

[89] Bioret F., Esteve R. et Sturbois A. (2009). Dictionnaire de la protection de la nature. Collection «Espaces et territoires», Presses Universitaires de Rennes, 537 p.

[90] Benkara E. (2014). Tableau de bord et Réserves naturelles. Mise en place d'une démarche pour évaluer l'efficacité de la gestion du patrimoine naturel de la Réserve Naturelle de la baie de Saint-Brieuc (France). Rapport final-version du 27. 02. 2014. Vivarmor Nature, Agence des Aires Marines Protégées, $135 \mathrm{p}$.

[91] Hocking M. and Phillips A. (1999). How well are we doing? Some thoughts on the effectiveness of protected areas. Parks, 9 (2): 5-14.

[92] Hockings M., Stolton S., Leverington F. and al. (2006). Evaluating Effectiveness: A Framework for Assessing Management Effectiveness of Protected Areas, Second Edition. $N^{\circ} 14$. UICN, Gland, Suisse. xiv + 105p.

[93] UICN-PACO (2012). Acteurs et gouvernance des aires protégées d'Afrique de l'Ouest: quelle contribution à la conservation ? Ouagadougou, BF: UICN/PACO, 171p.

[94] OECD (1993). Core set of indicators for environmental performance reviews. OCDE, Paris, http://www.virtualcentre.org/en/dec/toolbox/Refer/gd93179.p df, dernière visite du site effectuée le 15 février 2016.

[95] Requier-Desjardins M. (2012). Enjeux et modes d'intégration de la dimension socio-économique dans la surveillance environnementale. CIHEAM-IAMM, France, UMR MOISA / CSFD, Options méditerranéenes, $14 \mathrm{p}$.

[96] Hartley A., Nelson A., Mayaux P. and al. (2007). The Assessment of African Protected Areas. EUR 22780. A characterization of biodiversity value, ecosystems and threats, to inform the effective allocation of conservation funding. EN, Luxembourg: Office for Official Publications of the European Communities, 80p.

[97] Ntiranyibagira E. (2019). Conceptual and Analytic Model for Advanced Evaluation of Protected Areas' Global Evolutionary Trends: The Protected Areas' Trends Assessment and Adaptive Management on the Basis of Long-Term Conservation Objectives or PA-TAMCO Analytic Model. American Journal of Environmental Science and Engineering. Vol. 3, No. 1, 2019, pp. 8-16. doi: 10.11648/j.ajese.20190301.12.

[98] Niang C. I. (1990). Des crises écologiques en Occident au défi énergétique en Afrique. In Revue Internationale des Sciences Sociales, $n^{\circ} 124$.
[99] FAO (2012). Situation des forêts du monde. Dixième Edition, $66 \mathrm{p}$.

[100] Ghimire K. B. and Pimbert M. P. (1997) Social change and conservation. Earthscan, Genève, 352p.

[101] Chape S., Blyth S., Fish L., Fox P. and Spalding M. (compilers) (2003). 2003 United Nations List of Protected Areas. IUCN, Gland, Switzerland and Cambridge, UK and UNEP-WCMC, Cambridge, UK. ix + 44p.

[102] Carrere R. and Bravo E. (2004). Protected areas: Protected against whom? Oilwatch \& WRM, janvier 2004.

[103] Hughes R. H. et Hughes J. S. (1992). Répertoire des zones humides d'Afrique. UICN, Gland, Suisse et Cambridge, Royaume Uni / PNUE, Nairobi, Kenya / CMSC, Royaume Uni. $\mathrm{xx}+808 \mathrm{pp}$.

[104] Weigel F. Y., Féral F. et Cazalet B. (2007). Les aires marines protégées d'Afrique de l'Ouest. Gouvernance et politiques publiques. Presses Universitaires de Perpignan, 232 p.

[105] UICN-PAPACO (2012). Renforcer la conservation des aires protégées d'Afrique. Synthèse de la rencontre de WEOTENGA. Burkina-Faso, 25-27 octobre 2011, 58p.

[106] Locke H. and Dearden P. (2005). Rethinking protected area categories and the new paradigm. Environmental Conservation, 32 (1): 1-10.

[107] Mac Chapin (2004). A challenge to conservationists. World Watch, vision for a sustainable world. WORLD WATCH magazine, 17-31.

[108] Balmford A., Bruner A., Cooper P. and al. (2002). Economic reasons for conserving wild nature, Science, 297, 950-953, DOI: $10.1126 /$ science. 1073947.

[109] Wilson K. E., McBride M. F., Bode M. and Possingham H. P. (2006). Prioritizing global conservation efforts. Nature, vol. 440 (7082): 337-340.

[110] Honloukou A. (2014). Pauvreté, communauté et État. Comprendre les enjeux stratégiques pour une meilleure gestion des aires protégées au Bénin, 78p.

[111] Katembo Vikanza P. (2011). Aires protégées, espaces disputés et développement au nord-est de la R. D. Congo. Thèse de Doctorat, Université Catholique de Louvain, 373p.

[112] Western D. and Wright M. (editors) (1994). Natural connections: perspectives in community-based conservation. First Edition, Island Press, Washington D.C, 600 pp.

[113] Oates J. F. (1999). Myth and reality in the rain forest: how conservation strategies are failing in West Africa. University of California Press, Berkely, CA, xxviii, 310 pp.

[114] Terborgh J., Van Schai C., Davenport L. C. and al. (editors) (2002). Making parks work: strategies for preserving tropical nature. Island Press, Washington D.C, 511p.

[115] Kanyamibwa S. (1998). Impact of war on conservation: Rwandan environment and wildlife in agony. Biodiversity and Conservation, 7: 1399-1406.

[116] Bonnin M. (2008). Les corridors écologiques: vers un troisième temps du droit de la conservation de la nature? Paris, L'Harmattan, 276p. 
[117] UICN (2014). Nouvelles des Aires Protégées en Afrique $n^{\circ} 74$.

[118] Sambou B. (2004). Evaluation de l'état, de la dynamique et des tendances évolutives de la flore et de la végétation ligneuses dans les domaines soudanien et sub-guinéen au Sénégal. Thèse de Doctorat d'Etat en Sciences Naturelles. Université Cheikh Anta Diop de Dakar (Sénégal), 209p.

[119] Dudley N. and Stolton S. (1999). Threats to forest protected areas: a survey of 10 countries. A research report from IUCN for the World Bank Alliance for Forest Conservation and Sustainable Use, $47 \mathrm{p}$.

[120] Umuziranenge G. (2019). Parks' Governance and Management in Rwanda: Opportunities and Challenges of the Community Participation for a Sustainable Conservation Case Study of Nyungwe National Park, International Journal of Environmental Protection and Policy. Vol. 7, No. 2, 2019, pp. 61-71. doi: 10.11648/j.ijepp.20190702.13.

[121] Webber A, Hill C, Reynolds V. 2007. Assessing the failure of a community-based human-wildlife conflict mitigation project in Budongo Forest Reserve, Uganda. Oryx 41: 177-84.

[122] Wanyingi, n. J. (2016). Determinants of human-elephant conflicts in shimba hills ecosystem, Kenya (doctoral dissertation).

[123] Ogunjobi, J. A., Halidu, S. K., Odebiyi, B. R., \& Fxentirimam, I. J. (2018). Crop raiding pattern of the African elephant (Loxodonta africana) in farms around Kamuku National Park, Nigeria. African Journal of Agriculture Technology and Environment Vol, 7 (2), 174-187.

[124] Wood A., Stedman-Edwards P. and Mang J. editors (2000). The Root Causes of Biodiversity Loss. World Wildlife Fund and Earthscan Publications Ltd. London, UK. Conservation $\begin{array}{lllll}\text { Ecology, } & 5 & \text { (1): } 12 . & \text { [Online]. URL: }\end{array}$ http://www.consecol.org/vol5/iss1/art12/.

[125] Binot A. et Joiris D. V. (2007). Règles d'accès et gestion des ressources pour les acteurs des périphéries d'aires protégées. VertigO - la revue électronique en sciences de l'environnement [En ligne], Hors-série 4 novembre 2007, mis en ligne le 11 novembre 2007, consulté le 21 avril 2016. URL: http://vertigo.revues.org/759; DOI: 10.4000/vertigo.759.

[126] Laslaz L. (2010). Parcs nationaux de montagne et construction territoriale des processus participatifs. Revue de géographie alpine/Journal of Alpine Research Vol. 98, 19p.

[127] Borrini-Feyerabend G., Farvar M. T., Nguinguiri J. C. et al. (2000). La gestion participative des ressources naturelles. Organisation, négociation et apprentissage par l'action. GTZ et IUCN, Kasparek Verlag, Heidelberg, 108p.
[128] Ribot J. C. and Peluso N. L. (2003). A Theory of Access. Wiley, Rural Sociology, 68 (2): 153-181.

[129] Nelson J. and Hossack L. (2001). Indigenous Peoples and Protected Areas in Africa: From Principle to Practice. Forest Peoples Program, 40p.

[130] Compagnon D. et Constantin F. (eds.)(2000). Administrer l'environnement en Afrique, Paris/Nairobi: Karthala/IFRA, $497 \mathrm{p}$.

[131] Bonnin M. et Rodary E. (2012). L'influence des services écosystémiques sur les aires protégées: premiers éléments de réflexion. Programme Serena, Document de travail ${ }^{\circ}$ 2012$02,17 \mathrm{p}$.

[132] Agrawal A. and Gibson C. C. (1999). Enchantment and Disenchantment: The Role of Community in Natural Resource Conservation. World Development, 27 (4): 629-649.

[133] UICN-PACO (2011). Parcs et réserves du Burundi: évaluation de l'efficacité de gestion des aires protégées. UICN/PACO, Ouagadougou, Burkina Faso, 107p.

[134] Soulé M. E. and Terborgh J. (1999). Conserving nature at regional and continental scales? A scientific program for North America. Bioscience, 49 (10): 809-817.

[135] Koontz A. (2008). The Conservation Marketing Equation. A manual for conservation and development professionals, Enterprise Works/VITA, USAID, 44p.

[136] WCMC (1992). Tropical managed areas assessment. Assessment the conservation status of the world's tropical forest: a contribution to the FAO Forest Resources Assessment 1990. WCMC, Cambridge, U. K, 428p.

[137] James A. N (1999). Institutional constraints on protected area funding. Parks, 9 (2): 15-26.

[138] Dubois G., Bastin L., Martinez Lopez J. and al. (2015). The Digital Observatory for Protected Areas (DOPA) Explorer 1.0. Report EUR 27162 EN, European Commission, Joint Research Centre, Institute for Environment and Sustainability, $60 \mathrm{p}$.

http://publications.jrc.ec.europa.eu/repository/bitstream/JRC9 5295/lb-na-27162-en-n\%20.pdf.

[139] Convention sur la Diversité Biologique (2010). Perspectives mondiales de la diversité biologique. Troisième Edition, Montréal, 94p.

[140] Agence Française de Développement (2014). Les aires protégées au service du développement durable, $8 \mathrm{p}$. 